\title{
PEMANFAATAN SERBUK GERGAJI SEBAGAI BAHAN BAKU BRIKET
}

\section{Pratiwi Nova Sari dan Sitti Aminah}

\author{
Jurusan Pendidikan MIPA \\ Fakultas Keguruan dan Ilmu Pendidikan Universitas Tadulako Palu
}

\begin{abstract}
Wood sawdust is one of the wastes from wood processing industry such as sawdust and peel residues. They are cheap raw materials and potential as a source of alternative energy by processing it into charcoal briquettes. The use of charcoal briquettes as a substitute for fossil energy sources has several advantages including the relatively less smoke emitted because it has been released during the carbonization process. They can be stored for a long time and the calor value is higher than wood. Charcoal briquettes are made from wood sawdust which is added by tapioca flour as glue. This study was conducted in two main stages, processing charcoal briquette and characterization. The characterization of charcoal briquettes are including density, moisture, ash, volatile substances levels, carbon bound, long flame and calor value. The results obtained from the charcoal briquettes are a density of $0.384 \mathrm{gr} / \mathrm{cm} 3$, a moisture of $2.44 \%$, an ash of $4.82 \%$, a volatile substance of $19.13 \%$, a carbon bond of $74.44 \%$, a briquette flame of 6.75 minutes/gr and the calor value of 5127 cal/gr. This study concluded that wood sawdust briquette has the potential to be used potentially as substitued for fuel.
\end{abstract}

Keywords: wood sawdust, briquette charcoal and tapioca flour

\section{PENDAHULUAN}

Indonesia merupakan negara yang kaya akan sumber daya alam yang sangat berlimpah, baik sumber daya alam yang dapat diperbaharui maupun tidak dapat diperbaharui. Sumber daya alam yang dapat diperbaharui seperti ekosistem hutan dan ekosistem hewan sedangkan sumber daya yang tidak dapat diperbaharui seperti minyak bumi, pertambangan emas, dan lain-lain (Indah Suryani, M. Yusuf Permana U., 2012)

Pada saat ini bahan bakar minyak (BBM) yang ada di pasaran disintesa dari produk petrokimia yang menggunakan bahan baku berasal dari minyak bumi. Ketersediaan minyak bumi sangat terbatas dan merupakan sumber daya alam yang tidak dapat diperbaharui, sehingga harganya akan semakin meningkat. Indonesia yang saat ini dikenal sebagai salah satu negara pengekspor minyak bumi diperkirakan juga akan mengimpor bahan bakar minyak pada 20 tahun mendatang, karena produksi dalam negeri tidak dapat lagi memenuhi permintaan pasar yang meningkat cepat akibat pertumbuhan penduduk dan Industry (Muzi \& Mulasari, 2014).

Cara mengatasi krisis Bahan bakar minyak (BBM) ini, pemerintah mengeluarkan kebijakan penghematan BBM yang dituangkan dalam Instruksi Presiden No. 10 tahun 2005. Inpres ini mengatur tentang langkah-langkah yang harus dilaksanakan dalam rangka penghematan BBM. Selain upaya penghematan, maka upaya untuk mengatasi krisis BBM juga dapat dilakukan dengan mengalihkan pemanfaatan energi fosil (minyak) kepada energi yang terbarukan (Renewable energy) atau bahan bakar nabati (Indah Suryani, M. Yusuf Permana U., 2012)

Beberapa energi alternatif yang dapat dikembangkan sebagai pengganti dari minyak bumi adalah gas bumi dan biomassa. Gas bumi dan batubara merupakan energi dari fosil sedangkan briket itu sendiri merupakan biomassa dan sering dimusnahkan dengan cara dibakar. Biomassa yang berasal dari limbah hasil pertanian dan kehutanan merupakan bahan yang tidak bernilai guna, tetapi dapat dimanfaatkan menjadi sumber energi bahan bakar alternatif, yaitu dengan mengubahnya menjadi suatu bahan bakar padat yang disebut biobriket (Dewi \& Hasfita, 2016).

Pengalihan penggunaan bahan bakar gas (elpiji) membuat sebagian masyarakat mengalami ketakutan akibat terjadinya beberapa ledakan tabung gas. Mengubah kebiasaan masyarakat yang semula menggunakan bahan bakar minyak dan kayu yang sudah berlangsung turun temurun bukanlah hal yang mudah. Namun hal ini harus dilakukan mengingat kebijakan pemerintah tentang harga minyak tanpa subsidi, sementara itu bahan bakar kayu kini kian sulit untuk di dapatkannya karena banyak beralinnya fungsi lahan tanaman pohon beralih menjadi pemukiman dan kawasan industri. Hal ini perlu diberikan solusi, dengan memberikan bahan bakar yang mudah didapat, terjangkau harganya dan tidak beresiko, terutama masyarakat yang merasa takut menggunakan bahan bakar gas (Brožek, 2016)

Salah satu potensi pemanfaatan biomassa yang bisa dilakukan di Indonesia adalah pemanfaatan limbah serbuk gergaji kayu menjadi bahan bakar briket, untuk limbah serbuk gergaji kayu berdasarkan data nasional badan pusat statistik (BPS) tahun 2008, produksi serbuk gergaji kayu di Indonesia sebesar $679.247 \mathrm{~m}^{3}$ dengan densitas $600 \mathrm{~kg} / \mathrm{m}^{3}$ maka didapat 407.548,2 ton. Jika dari kayu yang tersedia tedapat $40 \%$ yang menjadi limbah serbuk gergaji, maka akan didapat potensi pembuatan briket sebesar 163.319,28 ton/tahun. Berdasarkan data tersebut, diperoleh sebuah kesimpulan bahwa Indonesia dengan banyaknya potensi limbah serbuk gergaji sangat 
layak dimanfaatkan untuk pembuatan bahan bakar alternatif berupa briket dengan tujuan untuk mengurangi pemakaian konsumsi bahan bakar tak terbarukan (Arman, 2018).

Biomassa merupakan salah satu sumber energi yang melimpah serta dapat diperbaruhi. Biomassa umumnya berasal dari hasil sisa pengolahan pertanian. Biomassa ini dapat digunakan sebagai bahan bakar alternatif pengganti minyak bumi yang cocok dikembangkan di masyarakat. Limbah pertanian tersebut dapat diolah menjadi suatu bahan bakar padat buatan sebagai bahan bakar alternatif yang disebut briket (Purnomo dkk., 2015)

Briket dengan kualitas baik memerlukan komposisi yang tepat sehingga panas yang dihasilkan baik dan sesuai kebutuhan. Masalah utama dalam pembuatan briket adalah menentukan komposisi yang tepat sehingga nilai kalor briket semakin tinggi dan penggunaannya semakin meningkat. Selain itu tipe jenis perekat yang digunakan dalam pembuatan briket harus diperhatikan agar dapat diketahui ketahanan panasnya pada saat pembakaran (Purnomo dkk., 2015)

Berdasarkan uraian di atas maka peneliti akan mengkaji bagaimana memanfaatkan limbah serbuk kayu jati yang potensinya sangat besar sebagai bahan baku pembuatan arang briket sebagai bahan bakar alternatif yang diharapkan dapat meningkatkan nilai ekonomis dari serbuk kayu jati serta bisa membuka peluang dan pengadaan lapangan kerja baru.

\section{METODE}

Alat yang digunakan yaitu gelas ukur, oven, ayakan 45 (mesh), drum, ember, neraca digital, bomb kalorimeter, cetakan briket manual (pipa paralon), cawan porselin, desikator, tanur, panic, spatula dan gelas kimia.

Bahan yang digunakan yaitu sampel serbuk gergaji kayu, tepung tapioka dan aquades.

\section{Pembuatan arang}

Serbuk gergaji kayu jati dicuci dengan air untuk menghilangkan kotoran-kotoran yang menempel pada serbuk gergaji kayu, lalu mengeringkan dibawah sinar matahari sampai kering 1 jam. Kemudian mengarangkannya sebanyak $5 \mathrm{~kg}$ dengan cara memasukkan serbuk gergaji ke dalam drum pembakaran, lalu membakarnya kemudian drum ditutup 11 jam. Mengeluarkan arang dari drum pembakaran. Setelah menjadi arang, lalu keringkan dibawah sinar matahari. Kemudian menghaluskan arang menggunakan lumpang dan alu, lalu mengayak arang menggunakan ayakan 45 mesh (Dzulhijjah,2018).

\section{Pencampuran arang serbuk kayu dan perekat}

Pencampuran perekat dengan arang serbuk kayu menggunakan tepung tapioka untuk menyatukan arang serbuk kayu tersebut, perbandingannya adalah $1 \mathrm{~kg}$ Arang gergajian dan
$0,5 \mathrm{~kg}$ tepung tapioka. Tepung tapioka terlebih dahulu di rebus dengan air secukupnya lalu serbuk kayu di masukan dan di aduk hingga merata. Bahan yang sudah di campur lalu di cetak dan di tekan.Yang perlu diperhatikan dalam proses ini adalah komposisi dari arang gergajian dan campuran air serta tepung tapioka Pada proses pencairan tepung tapioka komposisi air harus tepat sehingga tidak terlalu encer atau sebaliknya tidak boleh kental, faktor ini sangat penting dalam proses perekekatan briket (Ariwidyanata dkk., 2019)

\section{Pembriketan}

Arang yang telah halus dicampurkan dengan bahan perekat tepung tapioka kemudian dimasukkan kedalam alat pencetak briket kemudian ditekan. Hasil cetakan kemudian di oven $105^{\circ} \mathrm{C}$ selama \pm 24 jam sampai benar-benar kering.

\section{Pengujian/Karakterisasi}

Setelah briket arang selesai dikeringkan dilakuan pengujian nilar kalor, kadar air, densitas, zat mudah menguap, kadar abu, dan kadar karbon (terikat).

Arang briket serbuk gergaji kayu jati yang dihasilkan kemudian dikarakterisasi atau diuji sifatsifatnya yaitu nilai kalor, densitas, kadar air, kadar abu, kadar zat mudah menguap, karbon terikat dan lama nyala arang briket.

\section{Densitas}

Langkah pengujian kerapatan yaitu menyiapkan peralatan yang digunakan termasuk benda uji, menimbang berat briket, mengukur volume briket (volume silinder) dan menghitung densitas dengan rumus :

$$
\rho=m / v
$$

(Kurniawan \& Syukron, 2019)

Dimana, $\rho=$ Berat jenis briket $; m=$ massa briket (gr); v =volume briket $\left(\mathrm{cm}^{3}\right)$

\section{Kadar air}

Memanaskan cawan porselin yang telah bersih ke dalam oven pada suhu $105^{\circ} \mathrm{C}$ selama 30 meni $t$, kemudian mendinginkan di dalam desikator selanjutnya menimbang bobot kosongnya (A). Menimbang sampel \pm 1 gram ke dalam cawan porselin yang telah diketahui bobotnya (B). Memanaskan sampel ke dalam oven pada suhu $105^{\circ} \mathrm{C}$ selama 1 jam. Mengangkat cawan kemudian mendinginkannya ke dalam desikator (C). Menghitung kadar air sampel dengan rumus berikut:

$$
\text { Kadar Air \% }=\frac{B-C}{B-A} \times 100 \%
$$

(Kurniawan \& Syukron, 2019) 
Diamana, $A$ = Massa cawan dengan karbon mulamula (gram) ; $\mathrm{B}=$ Massa cawan dengan karbon yang telah dikeringkan (gram); C = Massa Cawan (gram)

\section{Kadar abu}

Memanaskan cawan porselin ke dalam oven pada suhu $105^{\circ} \mathrm{C}$ selama 30 menit, kemudian mendinginkan di dalam desikator selanjutnya menimbang bobot kosongnya (G). Menimbang sampel \pm 1 gram ke dalam cawan porselin yang telah diketahui bobotnya (B). Memanaskan sampel ke dalam tanur dengan suhu $700^{\circ} \mathrm{C}$ selama 1 jam. Memindahkan cawan dari tanur kemudian mendinginkannya ke dalam desikator selama 30 menit $(F)$ kemudian menghitung Kadar abu sampel dengan rumus Berikut :

$$
\text { Kadar abu }(\%)=\frac{F-G}{B-G} \times 100 \%
$$

(Kurniawan \& Syukron, 2019)

Dimana, B = Massa cawan dengan Karbon mulamula (gram); $\mathrm{F}=$ Massa cawan dengan karbon yang telah dikeringkan (gram); $\mathrm{G}=$ Massa Cawan (gram)

\section{Laju nyala arang Briket}

Meletakkan berdiri arang briket uji, membakar dengan cara seperti pembakaran terhadap arang, perhitungan dimulai ketika arang briket menyala hingga arang briket habis atau telah menjadi abu dan perhitungan ini menggunakan stopwatch atau jam.

\section{Kadar zat mudah menguap (VM)}

Prosedur pengukuran volatile matter (VM) yaitu cawan porselin yang telah bersih di oven dengan suhu $105^{\circ} \mathrm{C}$ selama 1 jam. Mendinginkan dalam desikator selama 30 menit kemudian ditimbang bobot kosongnya (A gram). Menimbang briket sebanyak 1 gram dan dimasukkan kedalam cawan porselin yang sudah ditimbang bobot kosongnya (B gram). Mentanurkan pada suhu $350^{\circ} \mathrm{C}$ selama 1 jam dan didiamkan sampai dingin (C). Menghitung Kadar zat mudah menguap (VM) sampel dengan rumus berikut :

$$
\text { Kadar VM }(\%)=\frac{B-C}{B-A} \times 100 \%-\text { Kadar air }
$$

(Salim, 2016)

Dimana, $A=$ Massa cawan dengan karbon mulamula (gram); B = Massa cawan dengan karbon yang telah dikeringkan (gram) ; C = Massa Cawan (gram)

\section{Karbon terikat (Fixed Carbon)}

Penentuan karbon terikat adalah fraksi karbon dalam arang selain fraksi abu, zat mudah menguap dan air, perhitungan kadar karbon adalah sebagai berikut :

Kadar Karbon terikat $(\%)=100-(\mathrm{Ka}+\mathrm{Vm}+\mathrm{Abu})$
Dimana, Ka $=$ Kadar Air (\%); Vm = Kadar zat mudah menguap (\%); Abu = Kadar abu (\%)

\section{Nilai kalor}

Pengukuran nilai kalor dilakukan dengan menggunakan alat bom calorimeter. Mula-mula menimbang sampel \pm 1 gram ke dalam cawan. Menyiapkan rangkaian bom kalorimeter dan memasang cawan ke rangkaian bom kalorimeter. Menghubungkan rangkaian bom kalorimeter dengan kawat platina dan mengaturnya hingga menyetuh sampel. Memasukkan aquades sebanyak $1 \mathrm{~mL}$ ke dalam bejana bom calorimeter lalu memasukkan rangkaian bom kedalam becana. Menutup rapat lalu mengisi gas dengan tekanan 130 atm. Mengisi ember bom dengan dua liter aquades dan memasukkan ke dalam jaket bom. Memasukkan bejana bom kedalam ember lalu menutupnyan kemudian menjalankan mesin dan mencatat suhu awal setelah lima menit, menekan tombol pembakar dan membiarkan selama 7 menit. Mencatat suhu akhir dan mematikan mesin. Menghitung nilar kalor dengan rumus berikut :

$$
\begin{aligned}
& \text { Kalori }=\frac{\text { suhuakhir-suhu awal }}{\text { berat sampel }} \times 2458 \text { kalori } \\
& (\text { Kholik, 2019) }
\end{aligned}
$$

\section{HASIL DAN PEMBAHASAN}

\section{Densitas}

Densitas menunjukkan perbandingan antara berat dan volume arang briket. Besar kecilnya nilai densitas dipengaruhi oleh ukuran dan kehomogenan arang penyusun arang briket tersebut (Silviana \& Anggoro, 2017). Oleh karena itu arang briket serbuk gergaji pada penelitian ini dibuat dari arang serbuk gergaji kayu yang telah diayak terlebih dahulu mengunakan ayakan 45 mesh sehingga diperoleh arang serbuk gergaji yang homogen. Arang serbuk gergaji kayu homogen tersebut kemudian dibuat briket dengan menambahkan perekat tepung tapioka. Sifat alamiah bubuk arang cenderung saling memisah, tetapi dengan bantuan bahan perekat tapioka, butir-butir arang dapat disatukan dan dibentuk sesuai dengan kebutuhan (Olugbade dkk., 2019). Hal ini disebabkan karena bertambahnya bahan perekat maka ikatan antara partikel akan semakin kuat, kerapatan antara material juga semakin besar dan ruang pori lebih sedikit. Semakin tinggi kerapatan maka akan menghasilkan berat jenis atau densitas yang tinggi pula (Ariwidyanata dkk., 2019). Densitas atau berat jenis suatu bahan bakar berkaitan dengan nilai kalor bahan bakar tersebut. Semakin tinggi berat jenis bahan bakar, maka semakin tinggi nilai kalor yang diperoleh (Bimantara \& Hidayah, 2019).Densitas arang briket serbuk gergaji kayu pada perlakuan pertama 0,384 . Belum memenuhi standar SNI 


\section{Analisis kadar air}

Kadar air briket adalah perbandingan berat air yang terkandung dalam briket dengan berat kering briket tersebut setelah diovenkan (Firdaus dkk., 2019). Arang briket mempunyai sifat higroskopis yang tinggi. Sehingga penetapan kadar air bertujuan untuk mengetahui higroskopis arang briket hasil penelitian.

Penetapan kadar air arang briket sangat penting karena kadar air yang tinggi akan menyulitkan penyalaan dan mengurangi temperatur pembakaran. Selain itu,(Mardan dkk., 2019), mengemukakan bahwa kadar air briket sangat mempengaruhi nilai kalor atau nilai panas yang dihasilkan. Tingginya kadar air akan menyebabkan penurunan nilai kalor. Hal ini disebabkan karena panas yang tersimpan dalam briket terlebih dahulu digunakan untuk mengeluarkan air yang ada sebelum kemudian menghasilkan panas yang dapat dipergunakan sebagai panas pembakaran. Air yang berada pada permukaan briket akan langsung menguap, sedangkan untuk air yang berada di dalam akan mengalir keluar melalui pori-pori arang briket tersebut dan menguap.

Kadar air briket berpengaruh terhadap nilai kalor. Semakin kecil nilai kadar air maka semakin bagus nilai kalornya. Briket arang mempunyai sifat yang tinggi. Sehingga penghitungan kadar air bertujuan untuk mengetahui rendahnya kadar air pada briket arang. Hasil pengujian kadar air yang paling rendah yaitu 2,38 \% Sedangkan pengujian kadar yang paling tinggi terdapat pada perlakuan ke 2 yaitu $2,41 \%$. Hal ini disebabkan karena jumlah pori-pori masih cukup banyak dan mampu menyerap air, selain itu serbuk gergaji kayu masih mengandung komponen-komponen kimia seperti selulosa, lignin, dan hemiselulosa. Secara umum kadar air dari briket yang dihasilkan pada penelitian ini sudah memenuhi standar yang telah ditetapkan oleh beberapa negara untuk menggunakan briket sebagai bahan bakar, diantaranya Jepang (6-8\%),Amerika (maksimum $6,2 \%$ ), indonesia (maksimum $8 \%$ ).

Selain itu, kadar air briket dipengaruhi pula oleh waktu pada saat pengempaan dan pengeringan. Semakin lama pengempaan dan pengeringan yang dilakukan semakin banyak air yang terbuang. Hal ini disebabkan pada saat pengemipaan dan pengeringan yang dilakukan air akan ikut terbuang keluar .

Menurut juga mengemukakan bahwa faktor lain yang mempengaruhi kadar air adalah suhu dan cara penyimpanan. Hal ini disebabkan suhu akan menyebabkan kelembaban udara yang berdampak pada kadar air, begitu juga dengan cara penyimpanan akan mempengaruhi penyerapan air pada briket. (Yuliah dkk., 2017) bahwa luas permukaan bahan yang besar akan mengalami penguapan kadar air lebih cepat.

\section{Analisis kadar abu}

Abu adalah bahan yang tersisa apabila kayu dipanaskan hingga berat konstan (Riwan Manalu, 2010). Kadar abu ini sebanding dengan kandungan bahan anorganik di dalam kayu. Salah satu unsur utama yang terkandung dalam abu adalah silica dan pengaruhnya kurang baik terhadap nilai kalor dihasilkan (Anwari, 2015). Kadar abu yang tinggi didalam bahan bakar tidak mempengaruhi proses pembakaran tetapi mempersulit penyalaan bahan bakar. Menurut Hendra dan Darmawan dalam (Mardan ., 2019) Nodali Ndaraha (2010), semakin rendah kadar abu maka semakin baik kualitas briket yang dihasilkan. Menurut (Nurmalasari \& Afiah, 2017), semakin tinggi kadar perekat maka kadar abu yang dihasilkan akan semakin tinggi pula. Selain itu, tinggi rendahnya kadar abu juga dipengaruhi oleh tingginya kandungan bahan anorganik yang terdapat pada limbah biomassa.

Abu halus yang dihasilkan dari proses pembakaran arang briket serbuk gergaji untuk penetapan kadar abu berwarna keputih-putihan. Hasil penelitian Houston,D.F (1972) menunjukkan bahan abu serbuk gergaji mengandung silika $\left(\mathrm{SiO}_{2}\right)$ sebagai komponen utama $(86,90-97,30 \%)$ dan oksida lainnya dalam jumlah kecil (13,1-2.7\%) seperti $\mathrm{K}_{2} \mathrm{O}, \mathrm{Na}_{2} \mathrm{O}, \mathrm{CaO}, \mathrm{MgO}, \mathrm{Fe}_{2} \mathrm{O}_{3}, \mathrm{P}_{2} \mathrm{O}_{5}$ dan $\mathrm{SO}_{3}$ serta $\mathrm{Cl}$ dalam jumlah yang sangat kecil (Joddy Arya Laksmono). Hasil tersebut juga dapat menunjukkan komponen-komponen penyusun abu dari arang briket serbuk gergaji karena serbuk gergaji merupakan bahan bakunya.

Kadar abu arang briket serbuk gergaji pada penelitian ini cawan pertama 4,82 dan cawan kedua 1,08. Menurut penelitian (Djajaeng Sumangat \& Wisnu B, 2016) kadar abu yang tinggi berpengaruh terhadap nilai kalor yang dihasilkan, semakin tinggi kadar abu, maka semakin rendah kualitas briket yang dihasilkan. Dikarenakan di dalam abu terdapat silika yang dapat menurunkan nilai kalor. kadar abu yang dihasilkan pada penelitian ini sesuai dengan standar briket menurut SNI dengan nilai kadar abu maksimal $8 \%$. sesuai dengan standar briket dunia yaitu standar briket Inggris, yang dimana kadar abu briket Inggris berkisar antara 8-10\%.

\section{Kadar karbon terikat}

Kadar karbon terikat (Fixed Carbon) adalah fraksi karbon (C) yang terikat didalam briket arang selain fraksi air, abu dan zat mudah menguap. Nilai kadar karbon terikat diperoleh melalui perhitungan berat sampel (100\%) dikurangi dengan jumlah kadar air, kadar abu dan kadar zat mudah menguap. Dari hasil perhitungan diperoleh kadar karbon terikat pada serbuk gergaji lebih besar dibandingkan pada batubara.

Besarnya nilai karbon pada briket sangat bergantung pada hasil kadar air, kadar abu dan zat mudah menguap. Semakin rendah hasil kadar air, kadar abu dan zat mudah menguap, maka kadar karbon akan semakin besar. Begitu juga sebaliknya, jika semakin besar hasil kadar air, 
kadar abu dan zat mudah menguap, semakin rendah kadar karbonnya. Berdasarkan hasil tersebut dapat diketahui bahwa semakin tinggi kandungan karbon dalam briket, maka semakin lama waktu pembakaran dan waktu penyalaan relatif singkat. Dengan kata lain, jika kadar karbon dalam briket semakin tinggi maka semakin baik briket tersebut dijadikan bahan bakar (Aziz dkk., 2019).

Kadar karbon terikat pada penelitian ini adalah arang briket serbuk gergaji kayu yaitu perlakuan pertama $74,44 \%$ dan perlakuan kedua $77,38 \%$. Menurut (Ariwidyanata dkk., 2019) faktor jenis kayu sangat berpengaruh pada besarnya kadar karbon terikat dalam briket arang karena kandungan kimia didalamnya. Besarnya kandungan selulosa dalam kayu akan mempengaruhi kadar karbon terikat dalam briket arang. Kandungan selulosa yang tinggi akan menyebabkan kadar karbon terikat yang tinggi pula. Hal ini disebabkan komponen penyusun selulosa sebagian besar adalah karbon. Kadar karbon terikat ini memenuhi syarat mutu briket arang kayu (Minimal 69\%), standar jepang (60$80 \%)$ dan standar Inggris $(75,33 \%)$.

\section{Kadar zat mudah menguap}

Zat mudah menguap adalah hasil dari proses devolatilisasi. Zat mudah menguap terdiri dari gasgas yang dihasilkan dari bahan yang dapat terbakar (combustible matter) dan gas-gas yang dihasilkan dari bahan yang tidak dapat terbakar (non combustible matter) serta hidrokarbon. Bahan yang dapat terbakar setelah proses pembakaran menghasilkan gas antara lain $\mathrm{CO}_{2}$, $\mathrm{SO}_{2}$, dan uap air yang keluar sebagai gas asap atau gas buang sedangkan bahan yang tidak terbakar menghasilkan gas antara lain $\mathrm{O}_{2}$ dan $\mathrm{N}_{2}$ yang keluar sebagai gas asap.

Proses devolatilisasi yaitu proses dimana bahan bakar padat mulai mengalami dekomposisi, yaitu pecahnya ikatan kimia secara termal dan zat mudah menguap akan keluar dari partikel. Proses devolatilisasi terjadi setelah bahan bakar padat mengalami proses pengeringan dimana molekul air dalam bahan bakar padat diuapkan untuk partikel yang besar hasil devolatilisasi berpindah dari pusat partikel ke permukaan untuk kemudian keluar. Ketika zat mudah menguap keluar dari pori-pori bahan bakar padat, oksigen luar tidak dapat menembus ke dalam partikel, sehingga proses devolatilisasi dapat diistilahkan sebagai tahap pirolisis (M. Syamsiro dan Harwin Saptoadi, 2007).

Kadar zat mudah menguap pada penelitian ini pada perlakuan pertama $18,49 \%$ dan peralakuan kedua $19,13 \%$ Dilihat dari kadar zat mudah menguap konsentrasi tersebut, sesuai dengan standar briket menurut SNI yaitu minimal $15 \%$. Dan briket yang dihasilkan sesuai dengan standar briket dunia yaitu Jepang, dengan standar briket Jepang berkisar antra 15-30\%.

Menurut (Kurniawan \& Syukron, 2019), tinggi rendahnya zat mudah menguap briket arang yang dihasilkan dipengaruhi oleh jenis bahan baku, sehingga perbedaan jenis bahan baku berpengaruh nyata terhadap zat mudah menguap briket arang. Semakin tinggi zat mudah menguap, maka suatu bahan bakar akan semakin cepat terbakar dan akan menimbulkan asap yang lebih banyak pada saat briket arang dinyalakan. Hal ini disebabkan oleh adanya reaksi antara karbon monoksida ( $\mathrm{CO}$ ) dengan turunan alkohol yang ada pada arang.

\section{Lama nyala}

Uji lama nyala dilakukan untuk mengetahui berapa waktu arang briket serbuk gergaji menyala hingga arang briket serbuk gergaji kayu tersebut habis atau telah menjadi abu. Semakin lama waktu nyala arang briket serbuk gergaji kayu, maka semakin bagus pula kualitas arang briket serbuk gergaji kayu tersebut. Pada penelitian ini nyala arang briket serbuk gergaji kayu jati paling lama $6.75 \mathrm{menit} / \mathrm{g}$.

\begin{tabular}{|l|l|}
\hline Sampel & Lama nyala arang briket (menit/g) \\
\hline \multirow{2}{*}{ Arang Briket } & 6,75 \\
\cline { 2 - 2 } & 6,24 \\
\hline \multirow{2}{*}{ Rata-rata } & 6,495 \\
\hline
\end{tabular}

Tabel 4.6 menunjukkan bahwa lama nyala arang briket serbuk gergaji dari dua perlakuan dengan komposisi arang serbuk gergaji kayu dan bahan perekat (tepung tapioka) cenderung mengalami kenaikan walaupun turun sedikit pada perlakuan ke dua. Hal ini disebabkan karena adanya tepung tapioka yang mengikat arang serbuk gergaji kayu, sehingga memperlambat lamanya waktu nyala dari arang briket pada saat proses pembakaran briket tersebut. Semakin banyak arang yang ditambahkan, maka semakin banyak arang serbuk gergaji kayu yang terikat dan semakin lama nyala arang briket tersebut.

\section{Nilai kalor}

Penentuan nilai kalor bahan bakar sangat diperlukan karena berpengaruh pada pemanfaatannya, Nilai kalor adalah besarnya panas/energi yang diperoleh dari pembakaran suatu jumlah tertentu bahan bakar (Silviana \& 
Anggoro, 2017). nilai kalor sangat menentukan kualitas briket arang. Semakin tinggi nilai kalor bakar briket arang, semakin baik pula kualitas briket arang yang dihasilkan. Menurut Masturin (2002) nilai kalor dipengaruhi oleh kadar air dan kadar abu briket arang. Semakin tinggi kadar air dan kadar abu briket arang, maka akan menurunkan nilai kalor bakar briket arang yang dihasilkan. Menurut (Indrawijaya, 2019), pada umumnya serbuk kayu memiliki nilai kalor 4018,25 $\mathrm{kal} / \mathrm{g}$ hingga 5975,58 kal/g dan memiliki komposisi kimia yang bervariasi, bergantung pada varietas, jenis dan media tumbuh.

Pada perlakuan pertama menunjukkan bahwa nilai kalor tertinggi sebesar $5127 \mathrm{kal} / \mathrm{g}$ sedangkan nilai terendah terdapat pada perlakuan kedua yaitu $5125 \mathrm{kal} / \mathrm{g}$. peningkatan nilai kalor pada briket yang dihasilkan menunjukan bahwa arang serbuk gergaji memang memiliki nilai kalor tinggi. Berdasarkan dari hasil penelitian ini standar nilai kalor briket sesuai dengan nilai SNI dengan standar nilai kalor minimal 5000 kalori/gram sedangkan menurut Sudarsi nilai kalor briket arang sebesar 6000 kalori/gram(Nilai dkk., 2013)

\section{UCAPAN TERIMA KASIH}

Penulis mengucapkan terimah kasih kepada pihak yang membantu penelitian ini khususnya kepala Laboratorium Kimia Fakultas Keguruan dan IImu Pendidikan Univesitas Tadulako, sehingga penelitian ini berjalan dengan baik.

\section{DAFTAR PUSTAKA}

Ariwidyanata, R., Wibisono, Y., \& Ahmad, M. (2019). Karakteristik Fisik Briket dari Campuran Serbuk Teh dan Serbuk Kayu Trembesi ( $S$ amanea Saman ) dengan Perekat Tepung Tapioka Physical Characteristics of Briquettes from Tea Powder Mixture with Adhesives from Tapioca. 7(3), 245-252.

Arman, M. (2018). Pirolisis Bahan Batubara Dan Serbuk Gergaji. Journal Of Chemical Process Engineering, 03(02), 27-32.

Aziz, M. R., Siregar, A. L., Rantawi, A. B., \& Rahardja, I. B. (2019). Pengaruh Jenis Perekat Pada Briket Cangkang Kelapa Sawit Terhadap

WaktuBakar.Jurnal.Umj.Ac.Id/Index.Php/Sem nastek, 04, 1-10.

Bimantara, S. E., \& Hidayah, E. N. (2019). Pemanfaatan Limbah Lumpur Ipal Kawasan Industri Dan Serbuk Gergaji Kayu Menjadi Briket. Jukung (Jurnal Teknik Lingkungan), 5(1),21-27.

https://doi.org/10.20527/jukung.v5i1.6192

Brožek, M. (2016). The effect of moisture of the raw material on the properties briquettes for energy use. Acta Universitatis Agriculturae et Silviculturae Mendelianae Brunensis, 64(5), 1453-1458.

Dewi, R., \& Hasfita, F. (2016). Pemanfaatan Limbah Kulit Jengkol (Pithecellobium Jiringa)
Menjadi Bioarang Dengan Menggunakan Perekat Campuran Getah Sukun Dan Tepung Tapioka. Jurnal Teknologi Kimia Unimal, 5(1), 105.

Djajaeng Sumangat \& Wisnu B. (2016). Kajian Teknis dan Ekonomis Pengolahan Briket Bungkil Biji Jarak Pagar Sebagai Bahan Bakar Tungku. Buletin Teknologi Pasca Panen, 5(1), 18-26.

Firdaus, M., Nurdin, H., Sawit, B. K., Tapioka, T., \& Kalor, N. (2019). Menggunakan Perekat Tapioka Dan Damar. Jurnal of Multidicsiplinary Research and Development, 491-496.

Indah Suryani, M. Yusuf Permana U., M. H. D. (2012). Pembuatan briket arang Dari Campuran Buah Bintaro Dan Tempurung Kelapa Menggunakan Perekat Amilum. Jurnal Teknik Kimia No. 1, Vol. 18, Januari 2012, 18(1), 24-29.

Indrawijaya, B. (2019). Pemanfaatan Limbah Plastik Ldpe Sebagai Pengganti Agregat Untuk Pembuatan Paving Blok Beton. Jurnal Ilmiah Teknik Kimia, 3(1), 1-7.

Kholik, M. (2019). Pengaruh konsentrasi perekat terhadap karakteristik briket arang campuran serbuk gergaji dan tempurung kelapa. Jurnal Simetris, 10(2), 713-716.

Kurniawan, F. A., \& Syukron, A. A. (2019). Karakteristik Briket Bioarang dari Campuran Limbah Baglog Jamur Tiram (Pleurotus Ostreatus) dan Sekam Padi. Indonesian Journal of Applied Physics, 9(02), 76.

Mardan, E. F., Elektro, F. T., \& Telkom, U. (2019). Analisa Pengaruh Penambahan Bahan Aditif Pada Briket Analysis The Effect Of Additive Materials Addition On Nilai Kalor Kadar Air > 4000 kalori / gram. 6(2), 4876-4883.

Muzi, I., \& Mulasari, S. A. (2014). Perbedaan Konsentrasi Perekat Antara Briket Bioarang Tandan Kosong Sawit Dengan Briket Bioarang Tempurung Kelapa Terhadap Waktu Didih Air. Jurnal Kesehatan Masyarakat (Journal of Public Health), 8(1), 1-10.

Nilai, T., Dan, K., Pembakaran, K., Malakauseya, J. J., \& Sasongko, M. N. (2013). Pengaruh Prosentase Campuran Briket Limbah Serbuk Kayu Gergajian Dan Limbah Daun Kayuputih. Jurnal Rekayasa Mesin, 4(3), 194-198.

Nurmalasari, \& Afiah, N. (2017). Briket Kulit Batang Sagu (Metroxylon Sagu) Menggunakan Perekat Tapioka Dan Ekstrak Daun Kapuk (Ceiba pentandra). Jurnal Dinamika, 08(1), 110.

Olugbade, T., Ojo, O., \& Mohammed, T. (2019). Influence of Binders on Combustion Properties of Biomass Briquettes: A Recent Review. Bioenergy Research, 241-259.

Purnomo, R. H., Hower, H., \& Padya, I. R. (2015). Pemanfaatan Limbah Biomassa untuk Briket Sebagai Energi Alternatif. Prosiding Seminar Agroindustri Dan Lokakarya Nasional FKPTTPI, September, 2-3. 
Salim, R. (2016). Karakteristik dan Mutu Arang Kayu Jati (Tectona grandis) dengan Sistem Pengarangan Campuran pada Metode Tungku Drum (The Quality and Characteristics of Teak (Tectona grandis) Charcoal Made by Mixed Carbonisation in Drum Kiln). Jurnal Riset Industri Hasil Hutan, 8(2), 53-64.

Silviana, \& Anggoro, D. D. (2017). Use of epoxidized waste cooking oil as bioplasticizer of sago starch-based biocomposite reinforced microfibrillated cellulose of bamboo. Advanced Science Letters, 23(3), 2591-2594.

Yuliah, Y., Suryaningsih, S., \& Ulfi, K. (2017). Penentuan Kadar Air Hilang dan Volatile Matter pada Bio-briket dari Campuran Arang Sekam Padi dan Batok Kelapa. Jurnal IImu Dan Inovasi Fisika, 1(1), 51-57. 